\title{
Employing Value Chain Theory To Address COVID-19 Outbreak In Tourism Management: A Resilience and Stakeholder View
}

\author{
Biancone Paolo \\ Department of Management \\ University of Turin \\ Corso Unione Sovietica 218, Bis - 10134, Italy \\ Secinaro Silvana \\ Department of Management \\ University of Turin \\ Corso Unione Sovietica 218, Bis - 10134, Italy \\ Brescia Valerio \\ Department of Management \\ University of Turin \\ Corso Unione Sovietica 218, Bis - 10134, Italy \\ Calandra Davide \\ Department of Management \\ University of Turin \\ Corso Unione Sovietica 218, Bis - 10134, Italy
}

silvana.secinaro@unito.it

davide.calandra@unito.it

paolo.biancone@unito.it

valerio.brescia@unito.it

\begin{abstract}
The COVID-19 outbreak is causing severe damage to the tourism sector. Gradual restrictions are imposed by the world's governments to improve social distancing and control the number of infected people. It creates a collapse in the tourism demand showing an unusual situation.

The paper, after an in-depth analysis of the literature on the tourism value chain, aims to investigate actions and perspectives which influence tourism management in this challenging period.
\end{abstract}

The study uses grounded theory to determine significant elements regarding the management of tourism. Through forty semi-structured interviews with individual people, the paper proposes a model of tourism restart based on value chain theory.

The model finds out five relevant factors: tourist attractiveness (i.e., tourism flows, the composition of tourism flows, proximity tourism and coronavirus opportunities), receptive factors (i.e., new receptivity models, health, and prevention models), new business models (i.e., home delivery services, flow management applications, outdoor sports activities), digital divides (i.e., enhancement of the internet structure) and culture (i.e., new outdoor activities).

This study contributes theoretically to the value chain theory establishing a model for tourism regeneration. Additionally, the paper gives new practical insights in terms of resilience activities that tourism entrepreneurs could implement for tourists.

Keywords: Value Chain, Tourism, COVID-19, Proximity Tourism, Resilience Tourism.

\section{INTRODUCTION}

The tourism sector in all countries affected by the coronavirus (COVID-19) is under attack. The pandemic is causing severe damage to the industrial area in several countries all over the world, 
severely impairment economies, creating unemployment, business bankruptcies and several social costs [1], [2]. Practice and scientific studies show interruptions in traditional tourist flows that push institutions to innovate their offer towards new stakeholders [3]. The pandemic is recognised by global academics as a turning point for travel and tourism but also for institutions, identifying the external event as a catalyst for discussion in an industry that needs to become more ethical, responsible and sustainable [4]. Therefore, new strands of literature were born in the last year to encourage transformative thinking for tourism, making the COVID-19 an opportunity for development, mitigating problems such as overcrowding and environmental degradation [5]. Therefore, the change in life habits for health reasons expose several touristic companies to new economic scenarios, new tourism forms and customer needs [6]. Additionally, an event like COVID-19 with such a high impact has never been recorded from an economic point of view in the modern tourism sector [7].

On the economic value side, as suggested by the European Data Journalism Network, the tourism sector in many European countries represents more than $10.1 \%$ of GDP, which is the European mean. For instance, in Croatia (24.9\%), Greece (20.6\%), Portugal (19.1\%), Austria $(15.4 \%)$, Spain (14.6\%), Italy (13.2\%) and Slovenia (12.3\%), tourism as a percentage of GDP is much higher than this average, a sign of the importance of this sector [8]. Therefore, highlighting the importance of this sector, the need for new tourism solutions will be necessary, especially in those countries subject to governmental lockdown [9].

New solutions are therefore necessary, both on a theoretical level through the renewal of transformative thinking [4], [5] and further research on governance, structure, mechanisms and results of the value chain [10], and by practitioners through the search for organisational actions by institutions and stakeholders in the tourism sector [11]. The purpose of this paper is to address how the tourism sector is planning new activities in response to COVID-19.

Our contribution will focus on Italy, one of the first countries to be hit by the first wave of the pandemic at the end of February 2020 [12], causing unprecedented actions in the European context such as the total lockdown of social and productive activities [9]. As suggested by the study of Abu Bakar and Rosbi (2020), which also includes Italy, the pandemic led to the collapse of demand for tourist flows and booking prices causing structural changes in activities. Further studies are therefore needed to understand how tourist facilities are adapting.

Such actions are most vital after a few months of lockdowns of activities, as is the need to identify alternative solutions to cope with the pandemic upsurge. Therefore, this study, after an analysis of the literature considering the keywords "tourism value chain" and "Tourism" AND "COVID-19" on the Scopus database and Google Scholar, determines the actions influencing tourism management at the time of COVID-19 in a resilience context. Additionally, on a theoretical perspective, the paper redefines the value chain theory in tourism, considering the pandemic context. The central hypothesis will consist of testing whether the individual actions of the stakeholders will provide an evolved picture of the tourism value chain at the time of the COVID19.

Our study has an exploratory nature and lays the foundations for a new model of tourism enhancement based on the literature. Additionally, it reveals theoretical and practical implications. On the theoretical side, our paper adds evidence to the value chain theory in tourism by contributing directly to the emerging literature on COVID-19. Additionally, this study, as suggested by Niewiadomski [5], contributes to the general transformative thinking about tourism field. Finally, we contribute extending the discussion on the tourism value chain on the structure and mechanisms of evolution.

On a practical side, this paper helps tourism's managers to implement strategies in response to the crisis and to develop resilient actions based on the case study. Consequently, the most important implication is to provide a holistic approach to the reader based on the value chain theory for measuring one's resilience to tourism. 
The rest of the paper is organized as follows. The next section reviews the literature to identify the research gap identifying the value chain theory in tourism-the paper proceeds with the methodology section, which determines the method and its rationale. Then, we present the results of 40 semi-structured interviews. The discussion of its implications follows. Finally, the paper ends with conclusions, addressing limitations and future research perspectives.

\section{LITERATURE REVIEW}

\subsection{Evolution of Value Chain Theory In The Tourism Sector}

Value chain theory, or value chain analysis, is a theory introduced by Prof. Michael Porter in 1985 in the business and management field [14]. The strength of the approach consists in observing the company as a set of activities functional to design, produce, market, deliver and finally, support its product or service [15]. Triggered actions create value throughout the chain. The theory makes it possible to identify primary activities such as marketing and sales, logistics and services as essential drivers for production. Alongside this, support activities such as human resources, procurement, research and development and administrative management are defined [14].

The theory has been extended over the years in several sectors, including tourism. For instance, the contribution of von Friedrichs Grängsjö (2003) demonstrates the importance of networking between the closest destinations and attaches a high value to cooperation without forgetting competition. The same contribution shows how interdependence is a parameter that influences the whole tourism business. Therefore, the provision of synchronized services presupposes a value system between different organizations [17].

At the tourism level, value drivers can be identified in different stakeholders.

For example, individuals, public and hybrid organisations, enterprises involved are considered as nodes in the value chain [18]. Going into more detail, as identified by numerous scientific studies, travel agencies, hotels, catering, sports activities, shops and all related activities are nodes in the value chain [19], [20]. Designers also assume importance in the first part of the value chain as planners, together with public actors [10], [21].

A value variable is also defined by tourism chains, which are often interregional and proximity chains [22]. Additionally, the value chain theory allows us to understand tourist sources and actions such as tourists and the supply for the provision of services [23].

Therefore, value chain theory can be a flexible mental model [24]. For instance, the contribution of Zhang et al. (2010) finds that the flexibility required by environmental changes allows a simultaneous view of opportunities and uncertainties along the value chain.

Considering that, the theory highlights the need to assess the whole tourism value chain through multidisciplinary and flexible approaches. For example, the contribution of Yilmaz and Bititci discovers a unique model of value chain management, focusing on the end customer [20]. In other cases, such as the study of Romero and Tejada (2020), the authors investigate tourism intermediaries by focusing on and considering the hotel industry value chain [26]. Finally, the approach has also been applied to identify critical resources considering precise tourism targets such as business and leisure tourism [27].

Our contribution will make use of the theoretical flexibility demonstrated by the literature [24] to focus on tourism by identifying the critical resources needed in the COVID-19 period. Besides, the article will provide a unified response to complexity management, considering government measures and new customer demand for tourism service [28]. 


\subsection{COVID-19 Prevention Measures, New Customers' Demands and Tourism}

COVID-19 (SARS-CoV-2), severe acute respiratory coronavirus syndrome [29], appeared at the end of 2019 in China and the beginning of 2020 in European countries, causing serious problems to health and economic systems. From the beginning, the literature has tried to understand what the financial implications might have been, although not having full knowledge of the phenomenon but looking at the studies during the SARS epidemic in 2003 [30]. Also, in 2003, the first sector to be affected was tourism. [31]. Scientific studies helped to define the impact on the financial statements of companies in the industry, showing decreases in terms of short-term revenues, especially for the hotel sector [31]. In other cases, the literature focused on the integrated strategy needed to tackle the crisis caused by the epidemic [32]. Indications in terms of protection measures were already known and are reiterated by the World Health Organization with the current pandemic that requires more attention from the tourism sector to the health of customers [12], [28]. Among the main recommendations generated are measured to contain contagions, with total closures of entire nations, including Italy [9]. The primary indirect consequences on the tourism economy were the elimination of the demand for tourist packages and the temporary closure of shops, restaurants and public services to limit the contagion [33]. This led to the elimination of tourist demand and will lead to the timely reorganization of services, including health services, as soon as the containment measures are exhausted [33]. In particular, the pandemic containment measures consist of social distancing, quarantine measures for suspected infections, hand hygiene measures, the presence of health facilities that can provide a range of medical services and the ability of tourism structures to implement and respect social distancing measures [34]. Moreover, as pointed out by Anderson et al., "individual behaviour will be crucial to control the spread of COVID-19" [34]. As defined by Dinarto et al., COVID-19 can amplify a new form of tourist demand and new types of customer needs closer to destinations and will allow local tourism enterprises to improve their skills [35].

Therefore, as suggested by Brouder, the fundamental concepts of international tourism could show radical transformations on both the demand and the supply side of tourism. The author maintains a positive vision, stating that there is an opportunity for an institutional change of all stakeholders in the tourism industry [3]. Cheer also writes about human flourishing and the transformation of tourism into more impactful forms for all local communities [36]. Finally, Haywood concludes and provides additional motivation for our study by raising awareness among stakeholders in tourism areas around the need to coordinate with academics and embrace the search for the changing and redesigning of tourism [37].

\section{MATERIALS AND METHODS}

\subsection{Research Design}

The study uses an inductive qualitative methodology to investigate the individual actions of tourism stakeholders in response to the COVID-19 and to verify their validation within the value chain [38]. The inductive experience allows researchers to arrive at theoretical generalizations to fully understand the logic in a particular field of research [39]. For this reason, the interview method has been implemented to understand the issues, actions and phenomena concerning what can be obtained with closed-answer questionnaires [40], [41].

Consistent with the objective of the article to create a conceptual model concerning the policies that public decision-makers can select to cope with new tourism's needs, this paper use individual interviews [41].

Miles and Huberman (1994) defined a conceptual model as a visual or written product which explains the key factors, concepts or variables that comprise it either in a graphical form or in a narrative form. Developing a model also serves to present the presumed relationships that exist between the framework's elements. For the verification and determination of the new structure, the researchers investigated and described the tourism management experiences for Alpine resorts when the spread of COVID-19 first confronted them. More specifically, the authors adopted the approach of conducting interviews using the Webex-Cisco platform provided to the 
researchers (as the study was conducted during the period of isolation from March 2020 to midMay 2020). The theoretical framework was drawn up based on interpretations of the interviews that were then confirmed by parts of the reference literature. The objective of the conversation was to understand the approach of tourism decision-makers towards reopening and managing tourism flows during the COVID-19 era. The method adopted allowed us to discuss the phenomenon more intensively with the interlocutors, compared to a more straightforward questionnaire [40], [43].

The paper adopted a grounded theory (Glaser and Strauss, 1967) research design to analyze the qualitative data obtained through the individual interviews that were conducted [41], [44]-[46]. It is a research methodology developed in the context of the interpretative paradigm, which places its attention no longer on the search for the causes of social phenomena - as in the positivist paradigm - but on understanding and interpretation of the sense of action for the social actor. It is based on the simultaneity of the data collection and analysis phases, utilizing theoretical sampling and progressive coding of the data, according to a continuous comparison method. According to the methodology, the research is identified according to a theoretical sampling method based on a logic other than the statistical representativeness of the probabilistic sampling of quantitative research. It aims to guarantee the adherence of the interpretations of the reality of the phenomenon under study. It develops simultaneously with the phases of analysis through successive extensions of the participants' number and characteristics based on the needs for clarification and insights that emerge from these [47]. In the first phase of theoretical sampling, to allow us to grasp the social phenomenon under study in its complexity, the different contexts in which it can be found are examined, articulating them into socio-cultural and geographical macro areas.

This theory has been widely used in literature in several scientific disciplines, including the area of tourism research [44], [48]-[50]. Applying the grounded theory research approach means using a structured set of processes to develop a basic inductive theory on a given phenomenon [41], [51]. This theory has always been used if there are no other theories that can explain a given event. Kim et al. (2009) and later McGinley et al. (2014) used this theory to create a new theoretical model and to provide a conceptualization of the available data, thus allowing adequate interpretations in the field of tourism and hospitality.

We selected the people to be interviewed based on their activities, position and then adopted a snowball sampling process [52] (more details are available in paragraph 3.3). This technique allowed us to add more subjects beyond those that were first selected. For example, once we had interviewed the mayors of the mountain cities, we asked them which other items should be combined with the required characteristics that they mentioned. The main selection criterion for interviewee selection was people with a direct interest in the mountains that have a critical associative position and people who have decision-making roles at the mountain macro-area level. Porter's (1985) value chain theory allows systematization of the elements and a redefinition of the model concerning the highlighted items.

\subsection{Case Study Context}

The study considered the territory of the municipalities of the Milky Way (i.e., "Via Lattea"), also called the districts of the Olympic Valleys between Piedmont (Italy-North West) and France, cities that had a high influx of tourists after the Olympic Games following structural and systemic changes [53]. The geographical area is reported in Figure 1. 


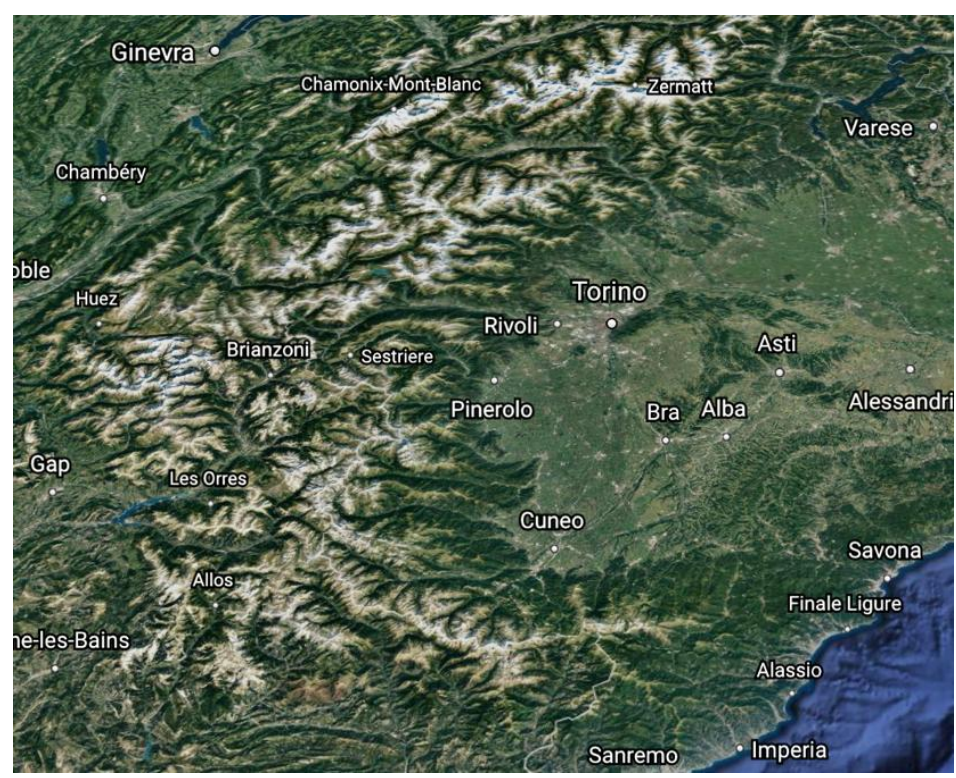

FIGURE 1: Map of the area under study. Source: Authors' elaboration on Google Earth.

The municipalities involved includes the cities of Bardonecchia, Cesana Torinese, Claviere, Oulx, Pragelato, Sauze d'Oulx, Sauze di Cesana, Sestriere and Usseaux. The territory is characterized as a highly touristic mountain area in both the summer and winter seasons. The total population of the area under analysis is less than 11,000, which increases during the months of winter skiing and outdoor activities in summer. The Albergo diffuso model developed during the Olympic Games of 2006 characterizes the area [54]. Giving a definition, as suggested by Confalonieri (2011), it is a traditional Italian form of hospitality which consists of a set of accommodation apartments located in different buildings across a town [55]. The general services such as the reception and orientation areas are located no more than 200-300 m from all the apartments.

The authors mapped the area in 2019 according to the characteristics that affect mountain tourism [56], allowing the identification of the sample considered for the analysis (Appendix Table 1).

The following Figure 2 shows the detailed registered population data (based on the National Institute of Statistics-ISTAT) in the area under investigation. Its proximity conditions the type of border tourism found in this location to France and Germany, which impacts the sample that was considered. Figure 3 identifies the origins of tourists entering the area under study. 


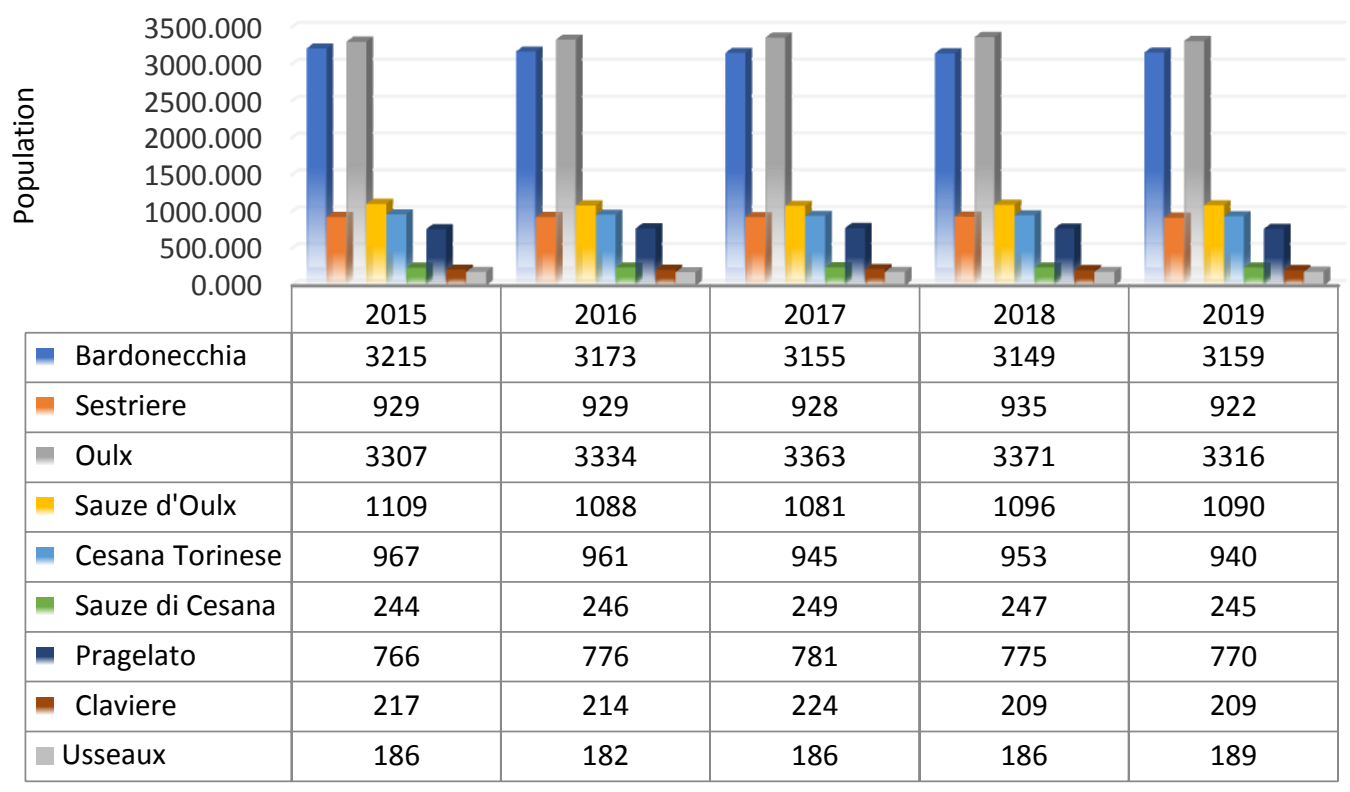

FIGURE 2: Population. Source: Authors' elaboration on National Institute of Statistics (ISTAT).

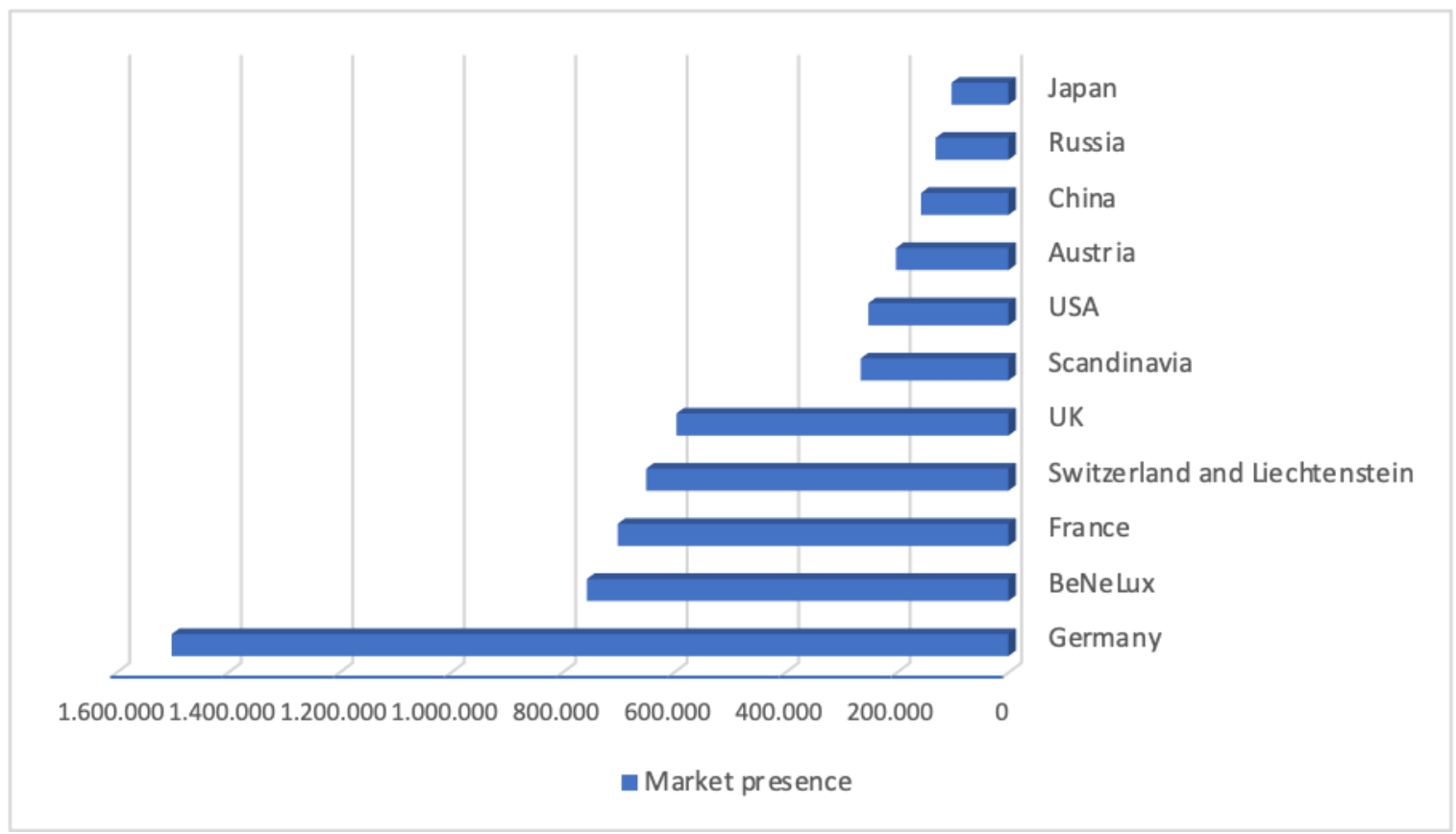

FIGURE 3: Origin of the tourists in the area under analysis. Source: Authors' elaboration on ISTAT.

As discussed by Dansero and Puttilli [53], this area was the location for the Turin 2006 Winter Olympic Games. As explained by the authors, the mega-event represented an excellent opportunity for the regeneration of the site by creating a set of tangible and intangible territorial assets that are still available to residents and tourists today.

The territory has 462 accommodation facilities as well as hundreds of houses located in the area, 201 restaurants and 19,950 beds, with an average of 4.6 days of stay per subject, as well as a yearly average number of tourists of $1,200,011$. Although the type of tourism is seasonally linked 
to skiing activities, summer trekking and mountain tourism are also common. Currently, the policies adopted in the neighbourhood provide for the recovery of unused and incapacitated properties with tax breaks linked to their restructuring for tourism purposes. The tax concessions, different from and additional to national tax breaks, also impact the structures already present and allow adjustments and renovations referred to by the proposed model.

\subsection{Interview and Data Analysis}

The investigation started by recruiting nine participants from March 2020 to mid-July 2020 for indepth individual pilot interviews using the semi-structured interview technique. The interviews lasted between 45 minutes and one hour and were conducted in Italy subject to movement restriction measures [9]. The objective of the interviews was to identify the themes of the tourist restart and the priorities at the time of COVID-19 for mountain tourism.

Among the issues and topics addressed, we considered a pool of items that refer to the expectation of tourist flows, hospitality, catering, entertainment, shopping, and the digital divide theme.

The guide for the interviews we adopted consisted of 15 questions. The semi-structured model allowed us to obtain introductory information, including informed consent to the interview and demographic characteristics of the interlocutors. The questions we asked had an open structure and consisted of three categories and focused on analyzing the current and future situation of high-altitude tourism in mountain cities.

The first section investigated the individual's approach to the current situation of COVID-19 (e.g., how can COVID-19 be an opportunity for the mountain territory? How do you see the transformation of the region occurs during the times of COVID-19? What do you think are the priorities for mountain tourism because of COVID-19?). The second section provided questions regarding reopening (e.g., what experience is the territory gaining for the safe reopening of restaurants? What opinions have you gathered on the reopening of the shopping areas for tourists? Why do you think that tourists want to return to mountain tourism as soon as possible?). The third section asked questions about business models linked to the mountain economy (e.g., do you think that the business model of high-altitude catering should change? How do you think traditional hotels can safely reopen? Do you believe that there could be a greater valorization of structures such as the 'Albergo diffuso' model?). The fourth section included questions of opinion and sentiment (e.g., why should tourists return to local mountain tourism? Do you expect international or just national tourists to return?). Finally, the fifth section obtained demographic and background information from respondents such as their age, education, nationality, and occupation.

The fieldwork, although mediated by a technological tool due to the restrictions on movement in our country, allowed us to conduct semi-structured interviews using standardized questions with the use of exact answers. We believe that this has greatly encouraged the full expression of our respondents. Between May and August 2020, we conducted 40 interviews with people living in Italy. All interviews were conducted in Italian by academic experts. The research team carried out the selection of respondents by applying the methodology of targeted sampling. According to Silverman, in the design and conduct of interviews, researchers can rely on multiple interviews by selecting their respondents based on the specific interest groups to which the research is directed [57]. The sampling framework is divided into subsections, which include interest groups; the starting cluster consists of all identifiable stakeholders, and the subjects are randomly selected from a subsection of different groups to maximize the range of perspectives investigated in the study [58].

The adoption of grounded theory, defined as the development of theory and understanding the fundamental social and economic problem concerning the model of the social context, allows a complete analysis with a selection of between 20 and 50 subjects representative of the context of the Olympic Valleys [44], [46], [59]. Specifically, stakeholder categories were chosen while 
considering the analysis of Presenza and Cipollini (2010) as being hotels, residences and Albergo diffuso entrepreneurs, tourism consortiums with food and beverages and finally sports firms [60].

Therefore, we have started to enroll participants in the study, considering their primary activity around the analysis. We included stakeholders such as hotel and sales entrepreneurs, sports entrepreneurs, public decision-makers, trade associations.

Additionally, among the interviewees' positive selection criteria, the researchers considered:

- public stakeholders with decision-making powers in the tourism sector, since governments need to provide a regulatory framework for business activities [61], [62]. On the other hand, we exclude all public stakeholders without tourism relevance.

- private stakeholders that were randomly interviewed if they belong to the shopping, sport and hospitality sectors [63], [64].

The second phase envisaged by the grounded theory led to collecting information through an indepth interview [45]. The data collection was carried out according to a defined methodological process that foresees during the observations that field notes are taken and once completed, and reports are processed. The interviews, conducted according to a semi-structured scheme, interviews provide on average from 8 to 12 interviewees [65], conducted in an unstructured manner, are recorded and transcribed texts and documents relating to the subject under investigation, concerning a specific period [66]. The texts thus obtained constitute the material for analysis and codification [67].

Additionally, after considering the results of O'Sullivan, the researchers included female interviewers for the greater capacity for empathy. We also employed semi-structured questions, as the final answers provided by the respondents were shown to be more accurate during semistructured interviews [68]. The sample was balanced between men and women to give a maximum representation of reality and presented non-random sampling linked to the qualitative research conducted [58]. Furthermore, women can be more expressive, more interactive and more empathic than men [69].

The content of the interviews was then accurately translated by the authors for this article. The content of the conversations was digitally transcribed with the consent of the participants.

The analysis of the interviews was done promptly, so it would be based on what was still present in the researchers' memories. The relevant concepts that emerged from the interviews were coded using the MAXQDA 2020 software [70]. This made it possible to create macro-items and establish images that were further analyzed and added as the researchers conducted the interviews. Additionally, as suggested by Kuckartz and Rädiker (2019), MAXQDA allows researchers to conduct automatic and manual coding analysis [70]. The coding activity for this software integrates well with the grounded theory approach adopted [67]. In this case, manual coding was implemented by researchers pursuing a mixed process. In this vein, the codes were used to recall the categories of selected stakeholders. Therefore, we adopted a concept-based coding approach by selecting the information on the subject available in the interviews conducted. Specifically, the interactive interview data categorization function was used to list and assign the information gathered to each category.

The method of analysis of the discussions we used was structured in three main phases [41], [51]. First, we considered the data collected at the time of the interview. Subsequently, the researchers analyzed the individual transcripts individually, creating macro-codes. In the last phase, each researcher coded the collected information.

\subsection{The Profile of Respondents}

In Figure 4, we report a demographic and employment description of each of the interviewees. Of the 40 participants in the semi-structured interviews, most of them had a relatively high level of 
education. The respondents represented the mountain territory and were selected for their initiatives and connections with it. Among them, nine people were mayors of individual municipalities. Two people represented associations of municipalities. Three people represented consumer associations; two represented hoteliers associations, one described a restaurateurs association, and 17 were entrepreneurs which represented primary stakeholders in tourism [60]. Finally, considering the gender of the respondents, the selected decision-makers at a territorial level were $42 \%$ men and $58 \%$ women.

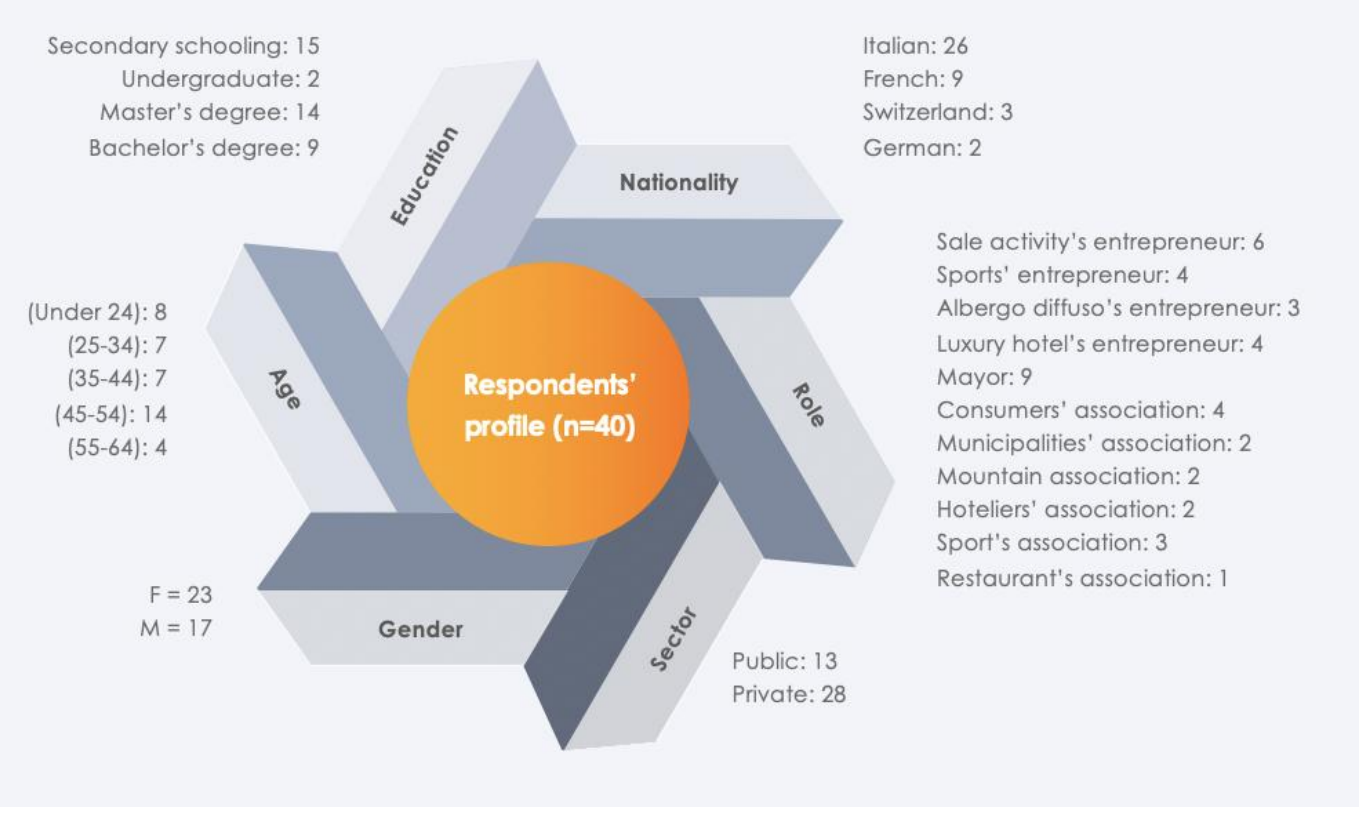

FIGURE 4: Summary of the respondents' profile $(n=40)$. Source: Authors' elaboration [71].

\section{RESULTS}

The qualitative results of our investigation of the 40 participants were classified into five variables: " tourist attraction", "receptive factors", "new business models", "digital divide" and "culture". The variables of tourist attractiveness included the respondents' expectations of the activation of tourism flows post-COVID-19, on the composition of arrivals compared to previous years, on proximity tourism and on the opportunities that COVID-19 can provide in the total redesign of the tourism experience. Receptive factors included respondents' reasoning on accommodation facilities, new accommodation models, and the health model adopted. Elements of business models had the respondents' experience of managing municipalities and their activities considering COVID-19 through dedicated home delivery services, activation of applications for tourism management and the possibility of starting outdoor sports activities on public land. Factors related to the digital divide included arguments about working capacity in mountain lands. Finally, factors related to cultural sites included new outdoor cultural activities. Below, all the manual coding categories extracted for the analysis are analyzed while considering the public and private types to which the respondents belong.

\subsection{Tourism Attraction}

The participants in this phase analyzed the situation involving the cases of contagion at national and international levels caused by governments' choices. Many of the respondents think that a solution to tourism flow challenges will only be possible once the lockdown measures have been 
completed and the health situation has improved. However, results are different for private and public stakeholders. For private stakeholders, the following comments were noted:

"If we think about tourism flows, until June 15 we imagine only national tourists. We think of the borders between France and Italy that are still closed due to the health emergency" (Respondents 3 and 26).

"Tourist flows have undergone a sudden change. As entrepreneurs, we register fast tourist flows in our mountains, often of Italian and border citizens who can move between neighbouring countries" (Respondents 22 and 24).

On the public side, we registered the following comments:

"Our citizens themselves are stuck at home. They can't move between cities, and this cancels tourist exchanges even between the same regions" (Respondent 1).

"The reopening of the borders will allow tourists from neighbouring countries to travel using transport such as cars. Our entrepreneurs confirm an increase in bookings, but we are witnessing a re-programming of the activities and the tourist offerings" (Respondents 2, 6 and 27).

The opening of tourist flows and interregional exchanges between countries is one of the essential elements of contemporary tourism [22]. Wang's contribution (2009) shows that during the Severe acute respiratory syndrome SARS epidemic of 2003, the multiple tourists flow in Taiwan reached their lowest historical level. Standards such as the safety and health of tourists remain the key to maintaining and restarting incoming tourism. This creates cultural and economic exchanges and provides enrichment for areas hosting new foreign incoming tourism flows. Also, high tourism flows provide more curiosity for the host country, creating more willingness for possible future travel [73]. However, during the time of COVID-19, as suggested by the World Health Organization (2020), it is essential to minimize trade. In response, many nations have induced total lockdown policies [9]. Looking at the literature from the SARS outbreak in 2003 confirms that tourism flows will be interrupted in the short term and then restarted as soon as movement restrictions are reduced [75]. At present, the policies that have been adopted to push towards proximity tourism to minimize contacts between subjects and different geographical areas [76].

Due to the natural interruption of tourism flows, stakeholders are managing the evolution of new services and opportunities.

"It is likely that, after this first moment, some tourist exchanges with neighbouring countries, people travelling by car and not by common means of transport could take place" (Respondent 4, public stakeholder).

"For the next season, I expect it will be more difficult to welcome tourists who get on a plane and travel for more than 3 hours than in previous years" (Respondent 13, public stakeholder).

"I think that the national and European policies to prevent COVID-19 will affect the composition of tourist arrivals" (Respondent 15, private stakeholder).

"As a luxury hotel in the Olympic mountains, we are offering a new service to tourists who decide to arrive by car from other countries. Thanks to this period, we have started important investments to acquire new tourists. These include an agreement with energy companies for the installation of electric vehicle recharging stations" (Respondents 34 and 38).

Although restarting international tourist flows can also bring about positive elements in terms of trade flows [77], [78], entry from neighbouring geographical regions can also benefit in a context of uncertainty [22]. As stated by Marrocu and Paci (2011), the exchange of tourist flows as in 
Europe favors the efficiency of the flows in terms of intangibles and infrastructure, with numerous territorial repercussions. The same author recalls and confirms what respondent 15 said about the evidence of being part of a community of states. At the time of COVID-19, the composition of arrivals will be conveyed by the health conditions; this event triggers the reopening of activities related to the world of hospitality [80, p. 19]. Additionally, as suggested by Sheller (2020), disasters such as the pandemic force us to rethink our activities sustainably by reformulating products and services in an ethical way [81]. What respondents 34 and 38 defined is also reflected in the literature; for example, the contribution of Borges-Tiago, Osvaldo and Tiago (2020) discovers many gray areas in sustainable tourism but also opportunities for entrepreneurs who can offer new services [82].

\subsubsection{Proximity Tourism}

Respondents are aware that the mountain tourism of the coming season mainly involves proximity tourism. The big cities could be a reservoir of tourists looking for a weekend getaway or a rediscovery of their region.

"If government lockdown measures diminish, I believe that the big tourist attraction poles close to big cities that are not well seen at the moment can win because of the rules of social distancing" (Respondent 2, public stakeholder).

"The mountain and its tourism have always been regulated. In my municipality, there are no problems of space because of the large uncultivated green areas and the paths that tourists follow with pleasure in summer and winter" (Respondents 9 and 21, public stakeholders).

"As soon as the rules of social distancing decrease, our target group will be families who have experienced dark times during this period. We will use targeted communication to attract local tourists even for a few hours of visit" (Respondent 13, public stakeholder).

"The tourists we are starting to receive are less than $100 \mathrm{~km}$ away. For us, it is a different challenge because they know our products and services. This year we have focused our marketing campaigns to attract more local tourists and convince them of the beauty of our mountains" (Respondents 36 and 40, private stakeholders).

As published in this journal by Rantala et al. (2020), local tourism enhances local destinations, short distances, and typically low-emission modes of transport. Our results confirm this statement and link the consequences of COVID-19 to tourism proximity as attraction [83]. Additionally, in a recent study by Jeuring and Haartsen (2017), the authors examined the concept of tourist proximity. After considering these results and comparing them with the interviews carried out, this contribution examines the imagery of travel and the idea of distance by focusing on regional tourism specific to mountain areas. Within this narrative, the role that governments and public stakeholders are playing in the management of COVID-19 also comes into question. As shown by the results of Nunkoo (2015), the concept of trust is also conveyed by national governments, and the development of tourism has a decisive impact on political trust.

\subsection{Receptive Factors}

\subsubsection{Luxury Hotels}

Respondents in this area are divided on their way of thinking about the luxury hotel as a tourist solution.

"I see the big hotel (i.e., belonging to a large group) as an asset to our community. The strength of the brand can attract many tourists in search of serenity. The same services that large facilities offer can benefit the whole community" (Respondent 10, public stakeholder).

"Although luxury hotel chains take all necessary measures to ensure clean and sanitized environments, I think people may be afraid to be in a large centralized facility. I think it's a psychological response to months of isolation" (Respondents 19 and 37, private stakeholders). 
According to Britton (2016), luxury hotels can attract tourist flows in specific geographical areas by maintaining their identity. As pointed out by Foroudi (2020), luxury hotels are very competitive, and the application of innovative marketing strategies on a large scale allows them to attract new tourists. Preliminary results from this stream of literature come from Hao, Xiao, and Chon (2020). They explore a COVID-19 management plan that includes new business choices such as multibusiness and multi-channel strategies, new services for tourists and digital transformation within the hotels. More generally, lacking reference literature, we could look at what happened during the SARS-2003 pandemic. During that period, in Taiwan, a study by Chen et al. (2003) showed that the reduction in tourist flows which occurred at that time led to a decrease in profits and share prices. This was due both to a lack of confidence in the hospitality industry during that period and a reduced readiness of the hotels themselves to handle the emergency.

\subsubsection{Albergo Diffuso}

The interviews revealed a hospitality model that characterizes the Italian market. Five respondents during a reflection on luxury hotel structures, on the other hand, wondered about the Albergo diffuso model as an alternative form of hospitality.

"I think COVID-19 is moving us towards a concept of slow tourism, sustainable and disconnected from concepts of big structures" (Respondent 5, public stakeholder).

"The Albergo diffuso has begun to exist in our municipalities and is made up of small structures scattered throughout the territory with equal standards of service for all" (Respondent 7, public stakeholder).

"The first tourist flows that we recorded were destined for the Albergo diffuso. This motivation was caused by the discretion of the service that is offered and the possibility of staying in flats that have been renovated but are separate from the central hub where people gather to enjoy the tourist services. This year we noticed the appreciation for these structures because they are suitable for social distancing" (Respondents 31 and 32, private stakeholders).

According to Vallone et al. (2013), the Albergo diffuso (AD) is an unconventional form of tourism that aims to enhance the resources of local communities. Moreover, it promotes territorial and cultural identities by differentiating between different tourism offers. What emerges from the interviews is an entirely Italian form of hospitality that positively influences the competitiveness of small areas and their repopulation [55], [90]. As confirmed by a subsequent study by Paniccia and Leoni (2019) [54], AD is a resilient model with useful co-evolutionary adaptations. The theoretical framework is also indirectly demonstrated by the contribution of Ruiz-Ballesteros (2017), who admits that alongside the concept of development and transformation, there is an increasing need to consider the objective of sustainability [91].

\subsubsection{Health Safety}

In terms of accommodation, the respondents agreed that significant tourist destinations would need to adopt advanced and fast healthcare solutions to follow tourist flows.

"In our area, we have five municipalities; every summer and every winter we ask for the strengthening of sanitary services due to the increase of incoming tourists" (Respondent 11, public stakeholder).

"We consider that every tourist season, we increase the number of doctors available for tourists in our municipality" (Respondents 8 and 12, public stakeholders).

"Our hotel entrepreneurs are progressively adapting their services to the health and safety measures recommended by the Italian Government following the guidelines of the World Health Organization. Efforts are manifold for the management of people in common places such as restaurants and bars" (Respondents 17, 25 and 33, public stakeholders). 
"As entrepreneurs of sports companies, we are adapting to health measures and through specialized marketing, we are contacting digital tour operators to make them perceive our mountains as being safe because they are outdoor places full of outdoor activities" (Respondents $14,16,30$ and 35 , private stakeholders).

According to Abu Bakar and Rosbi (2020), the reference health measures for COVID-19 will have to be timely. This was also indicated by Chen et al. (2007) in a similar discussion about the SARS outbreak. This means, for instance, that the response of the entire tourism sector must be coordinated to recreate the conditions for incoming tourism flows. The respondents were aware of and aligned with the relevant literature on this topic. Among the measures to be taken for living with the virus will be the provision of virus protection materials for all health workers on duty in mountain tourist resorts, as well as in cities [92]. Additionally, as suggested by Jiang and Wen (2020), hospitality measures could be beneficial for outdoor services [93].

\subsubsection{Smart Applications}

Some respondents also refer to the opportunity of using technology in contagion mapping as a protection measure against the virus.

"I think our tourists will be able to accept the opportunity to use contact tracing applications for greater peace of mind during the time they are visiting our municipalities" (Respondent 18, private stakeholder).

"As a public administration, we have made communications to encourage the use of social distancing control applications for both citizens and tourists" (Respondent 21, public stakeholder). The theme that the interviewees mentioned here are in line with the literature on COVID-19. The experience of countries such as South Korea, Singapore and Germany on the advice of the World Health Organization (WHO) shows that contact tracing is an effective means to control the spread of the virus [94]. In this context, tourist structures should also express their availability to share information on social distancing and health measures using smart applications [95, p. 19].

\subsection{New Business Models}

All respondents agree that in light of the health measures put in place by the Italian central government [9], restaurants will no longer be able to open as they have done so far for health reasons.

"I have a restaurant with 50 seats. Reading the health regulations, if I'm lucky, I can keep 25 seats and so can many other colleagues. I was considering that we should cut back on the seasonal staff that I used to welcome every year. I think that we must change the restaurants' business model; in this way, we will be able to pay our fixed costs" (Respondent 33, private stakeholder).

COVID-19 was an opportunity for us because we discovered digital and online sales. As a consumer association, we have developed a platform for the exchange of purchase and sales requests that brings together restaurants and customers, allowing them a method for fast home delivery" (Respondents 28 and 33, private stakeholders).

The literature has long reported on innovative forms of restaurants such as the use of home delivery using applications that can be useful in the new model of tourism value. In the investigation of Cho et al. (2019), mobile apps for food delivery at home take the opportunity to adapt to the catering sector. In a period with a significant impact on sales revenues due to government-imposed closures, apps can be used as an alternative strategy to increase sales revenues. This also allows for compliance with social distancing rules [1]. Therefore, small restaurant firms confirm Giacosa et al.'s (2017) study showing that business models are dominated by tradition and innovation in this sector [97].

Some respondents discussed the new sports models considering COVID-19. 
"If my municipality is known worldwide for its sporting events, now we will have to rethink everything. As a municipality, we manage more than 300 events in a year. Surely, we should change the way we organize. Still, we are thinking about how to innovatively make our tourists enjoy events that have never been done before" (Respondent 21, public stakeholder).

"We think of outdoor events, sports events for children and families in parks, in unspoilt green areas or with bicycles to make you appreciate nature even more" (Respondents 23 and 39, private stakeholders).

According to the conceptual framework of Gammon and Robinson (2003) and the results of Fourie and Santana-Gallego (2011) on mega-sport events, the link between sport and tourism is amplified by the increase in major events that bring notoriety to some geographical regions, especially in intangible ways. The literature was then expanded through reports from our respondents by them identifying sports events that mitigate the seasonality of tourist flow [100]. Therefore, the links between tourism and sport are mutually beneficial and, as stated by the respondents, deserve to be considered.

\subsection{Digital Divide}

A few respondents went beyond the tourist season topic, creating a discussion with researchers on the potential of information and communication technology (ICT) in tourism.

"One of the problems of mountain cities is the lack of Internet access, an essential infrastructure that allows smart working practices in times of lockdown; that's why we are working with some associations to seek funding to expand the speed of the network. An organized and common approach is needed" (Respondent 12, public stakeholder).

"During the lockdown, we tested new sales methods to be resilient. However, access to fast Internet is difficult, especially in some mountain locations. This leads to a loss of population and tourists who, even on holiday today, want to be connected" (Respondents 20, 29 and 32, private stakeholders).

According to Minghetti and Dimitrios (2009), tourism is a local and national source of wealth, and internet access is one of the requirements to reduce shortcomings in some tourist areas [102]. Moreover, adequate information and communication technology system in the tourism sector increases positive social and economic impacts from tourism in those areas [103]. During the time of COVID-19, this element allows tourist destinations to remain connected with tourists from all over the world and enable new tourism opportunities such as using the Internet of Things (Pizam, 2017). Therefore, as indicated by Maurer (2015), "a reasonable diffusion with information and communication technology (ICT) can be beneficial for both tourists and businesses".

\subsection{Culture}

Other respondents amplified the discussion by talking about the role of culture and mountain variables.

"The mountain is the birthplace of tradition; our territory has grown over the years and presents an incredible cultural heritage appreciated by the whole world" (Respondent 29, private stakeholder).

"Cultural and refugee workers should also rethink our activities in light of social distancing; in our case, it is not an opportunity but a necessity that we should respect to survive as small and medium firms" (Respondents 31 and 39, private stakeholders).

According to Richards (2018), cultural tourism covers numerous activities and research trends relevant to the intangible aspects of a context. As the author indicates, the creative breakthrough is an added value, and if linked to new technologies, it can have tangible benefits. The current management of access to museums, sites and attractions in Italy provides for a minimum spacing 
between subjects and access to stacks, which leads to a redefinition of the management of cultural areas differently from before, but which guarantees a restart for areas with a high intensity of cultural heritage presence [106].

\section{DISCUSSION}

The analysis of qualitative data from the study with existing theories from the literature led us to develop a scientific framework for the value of tourism. The results of our analysis resulting from the 40 semi-structured interviews were categorized into five main variables: tourism attractiveness, accommodation, business models, digital divide, and cultural elements (Figure 5). The combination of our results considering the creation of a new value framework for tourism at the time of COVID-19 can be analyzed using Michael Porter's (1987) value theory. Based on the model, several vital actions are in demand at the time of COVID-19 involving sustainability, safety, the need for timely health care and the improvement of quality of life for residents and tourists, all of which provide new touristic services and products. Therefore, as reported by Porter, actions to progress all those activities would enable an organization to proceed with value creation.

More specifically, the results suggest that the tourism value chain model has evolved due to COVID-19. Compared to the reference literature [20], [23], [24], our contribution shows how the supply aspects of tourism affect the actions that public and private stakeholders have taken to make the development of the tourist season possible. Through semi-structured interviews with operators in the sector, we went in-depth. We collected qualitative data on the actions they were developing for the reception of their first tourists after the lockdown ended. According to the research, the value chain model has evolved, incorporating new actions that the sector has developed.

Firstly, the limitation of tourist flows due to the closure of borders has led to focusing on domestic tourists with targeted marketing campaigns. The different composition of arrivals has also created new sustainable services for tourists. Therefore, based on our results, a form of tourism already known in the literature, proximity tourism [83], has been extended.

Secondly, tour operators also had to readjust their hospitality. New forms of tourist hospitality have been relaunched, such as the Albergo diffuso, which is particularly suitable for social distancing. Moreover, even luxury hotels have adopted new actions looking at the digital transformation of their reception methods, making tourists feel safe. For this reason, health security and the incentive to use digital applications for social distancing have been two new elements that have entered the list of the tourism discussion.

Thirdly, the results also suggest new actions for the creation of new business models such as delivery for small and medium-sized companies that have always been linked to traditional practices but have also been able to engage with process innovation [97].

Fourthly, the pandemic led to calls for valuable actions on information and communication technology to overcome the digital divide that now affects mountain resorts.

Fifthly, the rediscovery of proximity tourism and shorter tourist flows has triggered actions by tourism operators to enhance the cultural and historical heritage of mountain areas and outdoor sports areas that are particularly sought after by tourists.
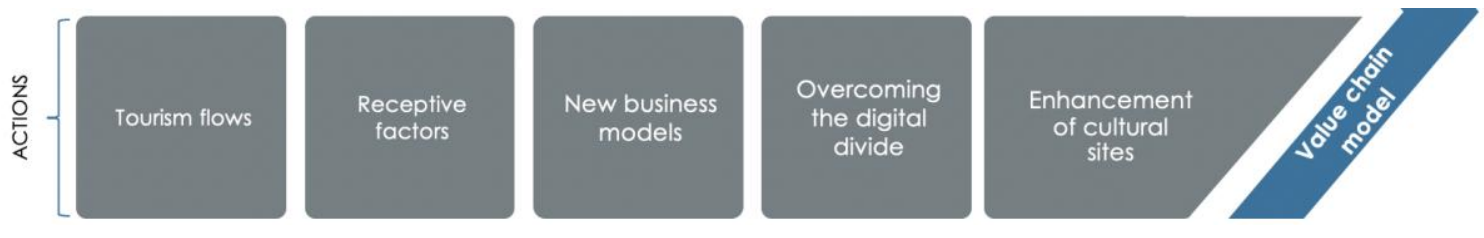

FIGURE 5: Tourism's value chain framework. Source: Authors' elaboration on Porter (1985). 


\section{CONCLUSIONS}

The study contributes to the novel stream of literature on tourism and COVID-19. To the best of our knowledge, the article has started its steps by checking whether the individual actions implemented by stakeholders will provide an evolved picture of the value chain. The hypothesis is born considering that new solutions to stimulate transformative thinking are necessary [4], [5]. Furthermore, recent research in terms of actions, structure and value mechanisms may be relevant to observe the changes taking place in the tourism sector [10].

Through a thorough review of the tourism literature and the effects of COVID-19 and the use of semi-structured interviews, the article identifies an adaptation of the value chain model. Furthermore, we suggest a scientific model for the valorization of tourism value chains in this pandemic period.

We found that the drivers of value in tourism are tourism flows with proximity tourism, new accommodation structures, health, safety and smart applications for COVID-19 preventions, new business models, the promotion of outdoor sports activities, enhancement of the network connection structure and improvement of outdoor cultural events. These elements were investigated by the experiences of the participants in the interviews on the management of restarting mountain tourism. Moreover, we provided a model of the connection that the existing literature on the value chain and complexity management can have with COVID-19.

As demonstrated by the proposed value chain model, there is an opportunity to rethink a series of coordinated actions to provide a management framework and coordinate the responses of the mountain tourism sector in a unified way. The framework presented brings together several stakeholders who have implemented the value chain actions recommended here. The request to interview people from both the public and private sectors served to create a holistic value chain model that brought together the views of mayors, entrepreneurs from various industries and trade associations. Therefore, this study aims to provide a timely response for the tourism sector, promoting collaboration and networking between all actors involved, as identified as being important in the literature by Manente (1999) [22].

Although the study cannot guarantee a generalization of the results given the specific characteristics of the territory, it is an initial step that provides an understanding of the complexity that the tourism sector is currently experiencing or will share as soon as lockdown measures are lifted [9]. The model and analysis can be reproduced in the future to cope with sudden and future pandemic events with similar epidemiological characteristics.

The paper, like any research, has some limitations. The first may be represented by the number of interviews conducted and the way they were done by an IT platform, which may have influenced the attention and concentration of participants concerning the questions proposed. Moreover, the result we have achieved here should be empirically tested as soon as the tourism sector is back in action. Finally, the study was conducted in Italy, as a country under restrictive measures with a limited sample of participants [9]. Nevertheless, the model underpins the tourism policies that will be adopted by mountain communities as future guidelines for action.

Despite the limitations, several implications can be made from this research.

First, on a theoretical level, our analysis has allowed us to discover some gaps in theory concerning the mapping of tourism actions in the COVID-19 period. Furthermore, by combining value chain theory with the tourism sector, the paper adds essential elements such as the coordination of efforts during extraordinary events such as the COVID-19 pandemic.

Second, considering the practitioner's view, the model provides an applied framework to measure and manage the value chain in the tourism sector. The approach may be useful for tourism managers to see how their choices are integrated into the actions that this article discovers. Our results aim to increase the satisfaction of customers who will experience first-hand the new 
services and opportunities implemented by the different stakeholders. Managers can find themselves in the indications in terms of actions and stakeholders to share for the management of pre- and post-pandemic tourism services. Tourists will therefore experience the activities along the entire value chain, providing satisfaction ratings that can be analyzed soon.

In conclusion, considering future research implications for researchers, we believe that it could be a challenging research stream. Considering the results obtained and the actions mapped, future scientific research could test whether and how tourism structures increase the level of sustainability during the COVID-19 period. Additionally, considering proximity tourism [83], future studies could investigate if people are willing to assess better the environment and natural heritage of tourist places visited. Finally, further research could test whether the re-organization of tourism services was a winning choice for tourism firms.

\section{Acknowledgments}

Thanks for the patience dedicated by all those who agreed to be interviewed despite the challenges caused by the pandemic.

\section{REFERENCES}

[1] Z. Ceylan. (2020, Aug.). 'Estimation of COVID-19 prevalence in Italy, Spain, and France', Sci. Total Environ., 729, p. 138817. doi: 10.1016/j.scitotenv.2020.138817.

[2] R. T. R. Qiu, J. Park, S. Li, and H. Song. (2020, Sep.). 'Social costs of tourism during the COVID-19 pandemic', Ann. Tour. Res., 84, p. 102994. doi: 10.1016/j.annals.2020.102994.

[3] P. Brouder. (2020, May.). 'Reset redux: possible evolutionary pathways towards the transformation of tourism in a COVID-19 world', Tour. Geogr., 22(3), pp. 484-490. doi: 10.1080/14616688.2020.1760928.

[4] F. Higgins-Desbiolles. (2020, Aug.). "The "war over tourism": challenges to sustainable tourism in the tourism academy after COVID-19', J. Sustain. Tour., 0(0), pp. 1-19. doi: 10.1080/09669582.2020.1803334.

[5] P. Niewiadomski. (2020, May.). 'COVID-19: from temporary de-globalisation to a rediscovery of tourism?', Tour. Geogr., 22(3), pp. 651-656. doi: https://doi.org/10.1080/14616688.2020.1757749.

[6] M. Sigala. (2020, Sep.) 'Tourism and COVID-19: Impacts and implications for advancing and resetting industry and research', J. Bus. Res., 117, pp. 312-321, Sep. 2020. doi: 10.1016/j.jbusres.2020.06.015.

[7] W. J. McKibbin and R. Fernando. (2020, Mar.). 'The Global Macroeconomic Impacts of COVID-19: Seven Scenarios', Social Science Research Network, Rochester, NY, SSRN Scholarly Paper ID 3547729. doi: 10.2139/ssrn.3547729.

[8] European Data Journalism Network. (2020). 'One in ten Europeans lives on tourism', European Data Journalism Network. https://www.europeandatajournalism.eu/News/Datanews/One-in-ten-Europeans-lives-on-tourism (accessed May 10, 2020).

[9] A. Tobías. (2020, Jul.). 'Evaluation of the lockdowns for the SARS-CoV-2 epidemic in Italy and Spain after one month follow up', Sci. Total Environ., 725, p. 138539. doi: 10.1016/j.scitotenv.2020.138539.

[10] H. Song, J. Liu, and G. Chen. (2012, Aug.). 'Tourism Value Chain Governance: Review and Prospects', J. Travel Res. doi: 10.1177/0047287512457264.

[11] World Economic Forum. (2020). 'COVID-19 could change travel - but not in the way you 
think', World Economic Forum. https://www.weforum.org/agenda/2020/09/covid-19-couldchange-travel-forever-but-not-in-the-way-you-think/ (accessed Nov. 07, 2020).

[12] A. Tuite, V. Ng, E. Rees, and D. Fishman. (2020). 'Estimation of COVID-19 outbreak size in Italy', Lancet Infect. Dis., 20(5), p. 537. doi: https://doi.org/10.1101/2020.03.02.20030049.

[13] N. Abu Bakar and S. Rosbi. (2020). "Effect of Coronavirus disease (COVID-19) to tourism industry', Int. J. Adv. Eng. Res. Sci., 7(4). doi: http://dx.doi.org/10.22161/ijaers.74.23.

[14] M. Porter. (1985). Competitive Advantage. New York: The Free Press.

[15] P. C. Ensign. (2001, Sep.). 'Value Chain Analysis and Competitive Advantage', J. Gen. Manag., 27(1), pp. 18-42. doi: 10.1177/030630700102700102.

[16] Y. von Friedrichs Grängsjö. (2003, Jan.). 'Destination networking: Co- opetition in peripheral surroundings', Int. J. Phys. Distrib. Logist. Manag., 33(5), pp. 427-448. doi: 10.1108/09600030310481997.

[17] J. Alcacer and M. Delgado. (2013, Nov). 'Spatial Organization of Firms and Location Choices Through the Value Chain'. doi: 10.1287/mnsc.2015.2308.

[18] I. Romero and P. Tejada. (2011, Apr.). 'A multi-level approach to the study of production chains in the tourism sector', Tour. Manag., 32(2), pp. 297-306. doi: 10.1016/j.tourman.2010.02.006.

[19] K. Weiermair. (2005, Jan.). 'Prospects for innovation in tourism: analysing the tourism value chain', J. Qual. Assur. Hosp. Tour., 6, pp. 59-72.

[20] Y. Yılmaz and U. S. Bititci. (2006, Jan.). 'Performance measurement in tourism: a value chain model', Int. J. Contemp. Hosp. Manag., 18(4), pp. 341-349. doi: 10.1108/09596110610665348.

[21] M. McLeod. (2020, Jan.). 'Understanding knowledge flows within a tourism destination network', J. Hosp. Tour. Insights, 3(5), pp. 549-566. doi: 10.1108/JHTI-02-2020-0017.

[22] M. Manente. (1999, Dec.). 'Regional and Inter-Regional Economic Impacts of Tourism Consumption: Methodology and the Case of Italy', Tour. Econ., 5(4), pp. 425-436. doi: $10.1177 / 135481669900500408$.

[23] Y. Liu, E. Dong, S. Li, and X. Jie. (2020, Jan.). 'Cruise Tourism for Sustainability: An Exploration of Value Chain in Shenzhen Shekou Port', Sustainability, 12(7). doi: 10.3390/su12073054.

[24] B. Haavengen, D. H. Olsen, and J. A. Sena. (1996, Nov.). 'The value chain component in a decision support system: a case example', IEEE Trans. Eng. Manag. 43(4), pp. 418428. doi: $10.1109 / 17.543984$.

[25] Q. Zhang, M. Vonderembse, and J.-S. Lim. (2010, Nov.). 'Value chain flexibility: A dichotomy of competence and capability', Int. J. Prod. Res., 40, pp. 561-583. doi: 10.1080/00207540110091695.

[26] I. Romero and P. Tejada. (2020, Mar.). 'Tourism intermediaries and innovation in the hotel industry', Curr. Issues Tour., 23(5), pp. 641-653. doi: 10.1080/13683500.2019.1572717.

[27] J. Y. Chung, Y.-K. Choi, B.-K. Yoo, and S.-H. Kim. (2020, Mar.). 'Bleisure tourism experience chain: implications for destination marketing', Asia Pac. J. Tour. Res., 25(3), 
pp. 300-310. doi: 10.1080/10941665.2019.1708760.

[28] C. Sohrabi, Z. Alsafib, N. O'Neill, M. Khan, A. Kerwanc, A. Al-Jabir, C. Iosifidis, R. Aghad. (2020, Apr.). 'World Health Organization declares global emergency: A review of the 2019 novel coronavirus (COVID-19)', Int. J. Surg., 76, pp. 71-76. doi: 10.1016/j.jjsu.2020.02.034.

[29] K. G. Andersen, A. Rambaut, W. I. Lipkin, E. C. Holmes, and R. F. Garry. (2020, Apr.). 'The proximal origin of SARS-CoV-2', Nat. Med., 26(4). doi: 10.1038/s41591-020-0820-9.

[30] S. Secinaro, D. Calandra, and P. P. Biancone. (2020, Jun.). 'Reflection on Coronavirus Accounting Impact on Small and Medium Sized Enterprises (SMEs) in Europe', Int. J. Bus. Manag., 15(7). doi: 10.5539/ijbm.v15n7p48.

[31] M.-H. Chen, S. (Shawn) Jang, and W. G. Kim. (2007, Mar.). 'The impact of the SARS outbreak on Taiwanese hotel stock performance: An event-study approach', Int. J. Hosp. Manag., 26(1), pp. 200-212. doi: 10.1016/j.ijhm.2005.11.004.

[32] P. Johnson Tew, Z. Lu, G. Tolomiczenko, and J. Gellatly. (2008, Jan.). 'SARS: lessons in strategic planning for hoteliers and destination marketers', Int. J. Contemp. Hosp. Manag., 20(3), pp. 332-346. doi: 10.1108/09596110810866145.

[33] V.-P. La, T.-H. Pham, M.-T. Ho, M.-H. Nguyen, T.-T. Vuong, H.-K.T. Nguyen, T. Tran, Q. Khuc, M.-T. Ho, Q.-H. Vuong. (2020, Jan.). 'Policy Response, Social Media and Science Journalism for the Sustainability of the Public Health System Amid the COVID-19 Outbreak: The Vietnam Lessons', Sustainability, 12(7). doi: 10.3390/su12072931.

[34] R. M. Anderson, H. Heesterbeek, D. Klinkenberg, and T. D. Hollingsworth. (2020, Mar.). 'How will country-based mitigation measures influence the course of the COVID-19 epidemic?', The Lancet, 395(10228), pp. 931-934. doi: 10.1016/S0140-6736(20)305675.

[35] D. Dinarto, A. Wanto, and L. C. Sebastian. (2020, Mar,). ‘Global Health Security - COVID19: Impact on Bintan's Tourism Sector'. Accessed: May 10, 2020. [Online]. Available: https://dr.ntu.edu.sg//handle/10356/137356.

[36] J. M. Cheer, 'Human flourishing, tourism transformation and COVID-19: a conceptual touchstone'. (2020, May). Tour. Geogr., 22(3), pp. 514-524. doi: 10.1080/14616688.2020.1765016.

[37] K. M. Haywood. (2020, May). 'A post COVID-19 future - tourism re-imagined and reenabled', Tour. Geogr., 22(3), pp. 599-609. doi: 10.1080/14616688.2020.1762120.

[38] H.-F. Hsieh and S. E. Shannon. (2005, Nov.). 'Three Approaches to Qualitative Content Analysis', Qual. Health Res., 15(9), pp. 1277-1288. doi: 10.1177/1049732305276687.

[39] K. Charmaz. (2006, Jan.). Constructing Grounded Theory: A Practical Guide Through Qualitative Analysis. London: Sage Publications.

[40] G. M. Breakwell, S. Hammond, and C. Fife-Schaw. (2000, Jun.). Research Methods in Psychology. London: Sage.

[41] A. L. Strauss and J. M. Corbin. (1990, Jan.). Basics of Qualitative Research: Grounded Theory Procedures and Techniques, Newbury Park. California: Sage.

[42] M. B. Miles and A. M. Huberman. (1994, Feb.). Qualitative Data Analysis: An Expanded Sourcebook. Sage Publications. 
[43] L. Leech Beth. (2002, Dec.). 'Asking Questions: Techniques for Semistructured Interviews', Political Science and Politics, 35(4), pp. 665-668.

[44] K. Charmaz. (2006, Jan.). Constructing Grounded Theory: A Practical Guide Through Qualitative Analysis. London: Sage.

[45] B. G. Glaser and J. Holton. (1967). 'Discovery of grounded theory'.

[46] B. G. Glaser and A. L. Strauss. (1967). The discovery of grounded theory: strategies for qualitative research, Adline de Gruyter. New York.

[47] N. Pandit. (1996, Dec.). 'The Creation of Theory: A Recent Application of the Grounded Theory Method', Qual. Rep., 2(4), pp. 1-15.

[48] J. Connell and A. Lowe. (1997). 'Generating grounded theory from qualitative data: the application of inductive methods in tourism and hospitality management research', Prog. Tour. Hosp. Res., 3(2), pp. 165-173. doi: 10.1002/(SICl)10991603(199706)3:2<165::AID-PTH87>3.0.CO;2-I.

[49] Y. G. Kim, A. Eves, and C. Scarles. (2009, Sep.). 'Building a model of local food consumption on trips and holidays: A grounded theory approach', Int. J. Hosp. Manag., 28(3), pp. 423-431. doi: 10.1016/j.ijhm.2008.11.005.

[50] S. McGinley, J. O'Neill, S. Damaske, and A. S. Mattila. (2014, Apr.). 'A grounded theory approach to developing a career change model in hospitality', Int. J. Hosp. Manag., 38, pp. 89-98. doi: 10.1016/j.ijhm.2014.01.003.

[51] A. Strauss and J. Corbin. (1994). 'Grounded theory methodology. Handbook of qualitative research', 17, pp. 273-285.

[52] C. Noy. (2008, Oct.). 'Sampling Knowledge: The Hermeneutics of Snowball Sampling in Qualitative Research', Int. J. Soc. Res. Methodol., 11(4), pp. 327-344. doi: $10.1080 / 13645570701401305$.

[53] E. Dansero and M. Puttilli. (2010). 'Mega- events tourism legacies: the case of the Torino 2006 Winter Olympic Games - a territorialisation approach', Leis. Stud., 29(3), Accessed: May 16, 2020. [Online]. Available: https://www-tandfonlinecom.bibliopass.unito.it/doi/full/10.1080/02614361003716966.

[54] P. Paniccia and L. Leoni. (2019). 'Co-evolution in tourism: the case of Albergo Diffuso', Curr. Issues Tour., 22(10), pp. 1216-1243. doi: https://doi.org/10.1080/13683500.2017.1367763.

[55] M. Confalonieri. (2011, Jun.). 'A typical Italian phenomenon: The "albergo diffuso"', Tour. Manag., 32(3), pp. 685-687. doi: 10.1016/j.tourman.2010.05.022.

[56] P. Fredman. (2008, Jun.). 'Determinants of Visitor Expenditures in Mountain Tourism', Tour. Econ. doi: 10.5367/000000008784460418.

[57] D. Silverman. (2010). Doing Qualitative Research. London: Sage Publications.

[58] A. Onwuegbuzie and K. Collins. (2007, Jun.). 'A Typology of Mixed Methods Sampling Designs in Social Science Research', Qual. Rep., 12(2), pp. 281-316.

[59] A. L. Strauss and J. M. Corbin. (1997). Grounded theory in practice. New York.

[60] A. Presenza and M. Cipollina. (2010, Jan.). 'Analysing tourism stakeholders networks', Tour. Rev., 65(4), pp. 17-30. doi: 10.1108/16605371011093845. 
[61] J. Robson and I. Robson. (1996, Nov.). 'From shareholders to stakeholders: critical issues for tourism marketers', Tour. Manag., 17(7), pp. 533-540. doi: 10.1016/S02615177(96)00070-2.

[62] R. E. Freeman and J. McVea. (2001). 'A Stakeholder Approach to Strategic Management', Social Science Research Network, Rochester, NY, SSRN Scholarly Paper ID 263511. doi: 10.2139/ssrn.263511.

[63] M. Sigala. (2014, Apr.). 'Wine tourism around the world: development, management and markets', J. Wine Res., 25(2), pp. 133-134. doi: 10.1080/09571264.2014.907136.

[64] M. Andrade-Suárez and I. Caamaño-Franco. (2020). 'The Relationship between Industrial Heritage, Wine Tourism, and Sustainability: A Case of Local Community Perspective', Sustainability, 12(18), pp. 1-21.

[65] N. King, C. Horrocks, and J. Brooks. (2018). Interviews in Qualitative Research, Second Edition. SAGE Publications.

[66] K. Roulston. (2010, Apr.). 'Considering quality in qualitative interviewing', Qual. Res. doi: $10.1177 / 1468794109356739$.

[67] R. N. Cheri Ann Hernandez. (2009, Nov.). 'Theoretical Coding in Grounded Theory Methodology', Grounded Theory Rev. Int. J., 8(3), Accessed: Sep. 16, 2020. [Online]. Available: https://doaj-org.bibliopass.unito.it.

[68] B. O'Sullivan. (2000, Sep.). 'Exploring gender and oral proficiency interview performance', System, 28(3), pp. 373-386. doi: 10.1016/S0346-251X(00)00018-X.

[69] A. L. Escobar, R. R. López, M. Pérez-Priego, and M. de los B. G.-M. García. (2020, Aug.). 'Perception, Motivation and Satisfaction of Tourist Women on Their Visit to the City of Cordoba (Spain)'. doi: 10.20944/preprints202008.0141.v1.

[70] U. Kuckartz and S. Rädiker. (2019). 'Working with Coded Segments and Memos', in Analyzing Qualitative Data with MAXQDA: Text, Audio, and Video, U. Kuckartz and S. Rädiker, Eds. Cham: Springer International Publishing, pp. 107-122.

[71] P. Biancone, S. Secinaro, V. Brescia, and D. Calandra. (2020, Jul.). 'Report of demographic and employment description of each of the interviewees. Covidless Approach \& Trust Project'. Zenodo. doi: 10.5281/zenodo.4262196.

[72] Y.-S. Wang. (2009, Feb.). 'The impact of crisis events and macroeconomic activity on Taiwan's international inbound tourism demand', Tour. Manag., 30(1), pp. 75-82. doi: 10.1016/j.tourman.2008.04.010.

[73] J. Alegre and M. Cladera. (2009, Jan.). 'Analysing the effect of satisfaction and previous visits on tourist intentions to return', Eur. J. Mark., 43(5/6), pp. 670-685. doi: 10.1108/03090560910946990.

[74] World Health Organisation. (2019). 'Coronavirus disease (COVID-19) advice for the public', 2020. https://www.who.int/emergencies/diseases/novel-coronavirus-2019/advice- forpublic (accessed May 10, 2020).

[75] J. Yuan, A. Y. Zeng, M. J. Skibniewski, and Q. Li. (2009). 'Selection of performance objectives and key performance indicators in public-private partnership projects to achieve value for money', Constr. Manag. Econ., 27(3), pp. 253-270.

[76] F. Romagosa. (2020, May). 'The COVID-19 crisis: Opportunities for sustainable and proximity tourism', Tour. Geogr., 0(0), pp. 1-5. doi: 10.1080/14616688.2020.1763447. 
[77] J. Zhang and C. Jensen. (2007). 'Comparative Advantage: Explaining Tourism Flows', Ann. Tour. Res., 34(1), pp. 223-243. doi: 10.1016/j.annals.2006.08.004.

[78] J. Pung and G. Chiappa. (2020, May). 'An exploratory and qualitative study on the meaning of transformative tourism and its facilitators and inhibitors', Eur. J. Tour. Res., 24, pp. 2404-2404.

[79] E. Marrocu and R. Paci. (2011, Aug.). 'They arrive with new information. Tourism flows and production efficiency in the European regions', Tour. Manag., 32(4), pp. 750-758. doi: 10.1016/j.tourman.2010.06.010.

[80] S. Gössling, D. Scott, and C. M. Hall. (2020, Apr.). 'Pandemics, tourism and global change: a rapid assessment of COVID-19', J. Sustain. Tour., 0(0), pp. 1-20. doi: 10.1080/09669582.2020.1758708.

[81] M. Sheller. (2020, Jul.). 'Reconstructing tourism in the Caribbean: connecting pandemic recovery, climate resilience and sustainable tourism through mobility justice', J. Sustain. Tour., 0(0), pp. 1-14. doi: 10.1080/09669582.2020.1791141.

[82] T. Borges-Tiago, O. Silva, and F. Tiago. (2020). 'Sustainable Tourism in Europe from Tourists' Perspectives', in Strategic Innovative Marketing and Tourism, Cham, pp. 565574. doi: 10.1007/978-3-030-36126-6_63.

[83] O. Rantala, T. Salmela, A. Valtonen, and E. Höckert. (2020, Jan.). 'Envisioning Tourism and Proximity after the Anthropocene', Sustainability, 12(10). doi: 10.3390/su12103948.

[84] J. H. G. Jeuring and T. Haartsen. (2017). 'The challenge of proximity: the (un)attractiveness of near-home tourism destinations', Tour. Geogr., 19(1), pp. 118-171. doi: https://doi.org/10.1080/14616688.2016.1175024.

[85] R. Nunkoo. (2015). 'Tourism development and trust in local government', Tour. Manag., 46@, pp. 623-634.

[86] S. Britton. (2016, Nov.). 'Tourism, Capital, and Place: Towards a Critical Geography of Tourism', Environ. Plan. Soc. Space. doi: 10.1068/d090451.

[87] P. Foroudi. (2020, Jul.). 'Corporate brand strategy: Drivers and outcomes of hotel industry's brand orientation', Int. J. Hosp. Manag., 88, p. 102519. doi: 10.1016/j.jijhm.2020.102519.

[88] D. Chen, T. Huang, and N. Hsaio. (2003). 'The management of citizen participation in Taiwan: A case study of taipei city government's citizen complaints system', Int. J. Public Adm., 26(5), pp. 525-547. doi: 10.1081/PAD-120019234.

[89] C. Vallone, P. Orlandini, and R. Cecchetti. (2013). 'Sustainability and innovation in tourism services: the Albergo Diffuso case study', Eurasian J. Soc. Sci., p. 14.

[90] P. Paniccia. (2012). 'Nuovi fermenti di sviluppo sostenibile nel turismo: l'esempio dell' "albergo diffuso". Tra borghi storici, residenze d'epoca e antichi casali rurali', 1, p. 26.

[91] E. Ruiz-Ballesteros. (2017). 'Socio-ecological balance in community-based tourism experiences: a resarch proposal.', Tour. Resil., pp. 41-52.

[92] F. Wu et al. (2020, Mar.). 'A new coronavirus associated with human respiratory disease in China', Nature, 579, pp. 1-8. doi: 10.1038/s41586-020-2008-3.

[93] Y. Jiang and J. Wen. (2020, Jan.). 'Effects of COVID-19 on hotel marketing and management: a perspective article', Int. J. Contemp. Hosp. Manag., 32(8), pp. 2563- 
2573. doi: 10.1108/IJCHM-03-2020-0237.

[94] G. lacobucci. (2020, Apr.). 'Covid-19: UK pledges to reintroduce contact tracing to fight virus', BMJ, 369. doi: 10.1136/bmj.m1591.

[95] V. Couture, J. I. Dingel, A. E. Green, J. Handbury, and K. R. Williams. (2020, Jul.). 'Measuring Movement and Social Contact with Smartphone Data: A Real-Time Application to COVID-19', National Bureau of Economic Research, Working Paper 27560. doi: $10.3386 /$ w27560.

[96] M. Cho, M. A. Bonn, and J. (Justin) Li. (2019, Jan.). 'Differences in perceptions about food delivery apps between single-person and multi-person households', Int. J. Hosp. Manag., 77, pp. 108-116 doi: 10.1016/j.ijhm.2018.06.019.

[97] E. Giacosa, A. Ferraris, and F. Monge. (2017). 'How to strengthen the business model of an Italian family food business', Br. Food J., 119(11), pp. 2309-2324. doi: 10.1108/BFJ03-2017-0124.

[98] S. Gammon and T. Robinson. (2003, Jan.). 'Sport and Tourism: A Conceptual Framework', J. Sport Tour., 8(1), pp. 21-26. doi: 10.1080/14775080306236.

[99] J. Fourie and M. Santana-Gallego. (2011, Dec.). 'The impact of mega-sport events on tourist arrivals', Tour. Manag., 32(6), pp. 1364-1370. doi: 10.1016/j.tourman.2011.01.011.

[100] J. Higham and T. Hinch. (2002, Apr.). 'Tourism, sport and seasons: the challenges and potential of overcoming seasonality in the sport and tourism sectors', Tour. Manag., 23(2), pp. 175-185. doi: 10.1016/S0261-5177(01)00046-2.

[101] V. Minghetti and B. Dimitrios. (2009). 'Digital Divide in Tourism', J. Travel Res., 49(3), pp. 267-281. doi: https://doi.org/10.1177\%2F0047287509346843.

[102] K. MacKay and C. Vogt. (2012, Jul.). 'Information technology in everyday and vacation contexts', Ann. Tour. Res., 39(3), pp. 1380-1401. doi: 10.1016/j.annals.2012.02.001.

[103] H. Thees, G. Erschbamer, and H. Pechlaner. (2020, Aug.). 'The application of blockchain in tourism: use cases in the tourism value system', Eur. J. Tour. Res., 26, pp. 2602-2602.

[104] C. Maurer. (2015). 'Digital Divide and Its Potential Impact on Cultural Tourism', pp. 231241.

[105] G. Richards. (2018, Sep.). 'Cultural tourism: A review of recent research and trends', J. Hosp. Tour. Manag., 36, pp. 12-21. doi: 10.1016/j.jhtm.2018.03.005.

[106] M. Lazzerini and G. Putoto. (2020, May). 'COVID-19 in Italy: momentous decisions and many uncertainties', Lancet Glob. Health, 8(5), pp. e641-e642. doi: 10.1016/S2214109X(20)30110-8. 


\begin{tabular}{|c|c|c|c|c|c|c|c|c|c|}
\hline Municipality & $\begin{array}{c}\text { Number of } \\
\text { beds }\end{array}$ & $\begin{array}{c}\text { Number of } \\
\text { hotels and } \\
\text { Albergo } \\
\text { Diffuso } \\
\text { models }\end{array}$ & $\begin{array}{l}\text { Number } \\
\text { of cafès }\end{array}$ & $\begin{array}{l}\text { Number of } \\
\text { restaurants }\end{array}$ & $\begin{array}{l}\text { Number } \\
\text { of pubs }\end{array}$ & $\begin{array}{c}\text { Number of } \\
\text { supermarkets }\end{array}$ & $\begin{array}{l}\text { Number } \\
\text { of } \\
\text { clothes } \\
\text { shops }\end{array}$ & $\begin{array}{l}\text { Number of } \\
\text { museums }\end{array}$ & $\begin{array}{c}\text { Number of } \\
\text { entertainment } \\
\text { venues }\end{array}$ \\
\hline Bardonecchia & 4,400 & 44 & 12 & 49 & 0 & 5 & 9 & 2 & 17 \\
\hline Cesana T.se & 1,795 & 34 & 5 & 45 & 1 & 3 & 0 & 1 & 14 \\
\hline Claviere & 1021 & 14 & 4 & 9 & 1 & 1 & 0 & 0 & 1 \\
\hline Pragelato & 2,018 & 27 & 2 & 13 & 1 & 4 & 1 & 2 & 0 \\
\hline $\begin{array}{l}\text { Sauze di } \\
\text { Cesana }\end{array}$ & 293 & 7 & 0 & 8 & 1 & 0 & 0 & 0 & 17 \\
\hline Sauze d'Oulx & 2592 & 55 & 18 & 27 & 3 & 4 & 4 & 1 & 1 \\
\hline Sestriere & 4,665 & 29 & 22 & 20 & 4 & 9 & 35 & 0 & 10 \\
\hline Oulx & 2,631 & 21 & 1 & 22 & 0 & 1 & 1 & 0 & 18 \\
\hline Usseaux & 530 & 9 & 1 & 8 & 0 & 0 & 0 & 1 & 3 \\
\hline TOTAL & 19,949 & 240 & 65 & 201 & 11 & 27 & 50 & 7 & 81 \\
\hline
\end{tabular}

\begin{tabular}{|c|c|c|c|c|c|c|c|c|c|}
\hline Municipality & $\%$ on total & $\%$ on total & $\begin{array}{c}\% \text { on } \\
\text { total }\end{array}$ & $\%$ on total & $\begin{array}{c}\% \text { on } \\
\text { total }\end{array}$ & $\begin{array}{l}\% \text { on total } \\
\text { total }\end{array}$ & on total & $\%$ on total \\
\hline Bardonecchia & $23 \%$ & $18 \%$ & $18 \%$ & $24 \%$ & $0 \%$ & $17 \%$ & $18 \%$ & $29 \%$ & $21 \%$ \\
\hline Cesana T.se & $9 \%$ & $14 \%$ & $8 \%$ & $22 \%$ & $9 \%$ & $11 \%$ & $0 \%$ & $14 \%$ & $18 \%$ \\
\hline Claviere & $5 \%$ & $6 \%$ & $6 \%$ & $4 \%$ & $9 \%$ & $5 \%$ & $0 \%$ & $0 \%$ & $1 \%$ \\
\hline
\end{tabular}




\begin{tabular}{|c|c|c|c|c|c|c|c|c|c|}
\hline Pragelato & $10 \%$ & $11 \%$ & $3 \%$ & $6 \%$ & $9 \%$ & $15 \%$ & $2 \%$ & $29 \%$ & $0 \%$ \\
\hline $\begin{array}{c}\text { Sauze di } \\
\text { Cesana }\end{array}$ & $1 \%$ & $3 \%$ & $0 \%$ & $4 \%$ & $9 \%$ & $0 \%$ & $0 \%$ & $0 \%$ & $21 \%$ \\
\hline Sauze d'Oulx & $13 \%$ & $23 \%$ & $28 \%$ & $13 \%$ & $27 \%$ & $15 \%$ & $8 \%$ & $14 \%$ & $1 \%$ \\
\hline Sestriere & $23 \%$ & $12 \%$ & $34 \%$ & $10 \%$ & $37 \%$ & $32 \%$ & $70 \%$ & $0 \%$ & $12 \%$ \\
\hline Oulx & $13 \%$ & $9 \%$ & $1 \%$ & $12 \%$ & $0 \%$ & $5 \%$ & $2 \%$ & $0 \%$ & $22 \%$ \\
\hline Usseaux & $3 \%$ & $4 \%$ & $1 \%$ & $4 \%$ & $0 \%$ & $0 \%$ & $0 \%$ & $14 \%$ & $4 \%$ \\
\hline \multicolumn{7}{|c|}{ TOTAL: $\mathbf{1 0 0} \%$} \\
\hline
\end{tabular}

Appendix A - Table 1. Analysis of the configurative characteristics of the context. 